Original Article

\title{
Deteksi Mikrobiota Plasenta Menggunakan PCR 16s rRNA Pada Persalinan Preterm
}

\section{Detection of Placental Microbiota Using 16s rRNA PCR in Preterm Labor}

\author{
Rajia*1, Muh. Nasrum Massi², Mardiana Ahamad $^{3}$ Sharvianty Arifuddin $^{4}$, Upik \\ Anderiani Miskad ${ }^{5}$
}

${ }^{1}$ Program Studi D3 Kebidanan, Institut Kesehatan dan Teknologi Buton Raya, Indonesia

${ }^{2}$ Fakultas Kedokteran Universitas Hasanuddin, Indonesia

${ }^{3}$ Departemen Kebidanan, Universitas Hasanuddin, Indonesia

${ }^{4}$ Departemen Obstetri dan Genekologi, Universitas Hasanuddin, Indonesia

${ }^{5}$ Departemen Patologi Anatomi, Universitas Hasanuddin, Indonesia

(r4jia10vinji@gmail.com, 085242450159)

\begin{abstract}
ABSTRAK
Penelitian ini bertujuan untuk mendeteksi bakteri dalam plasenta yang paling sering muncul dan besar risiko terhadap kejadian persalinan preterm menggunakan PCR 16S rRNA. Desain penelitian adalah hybrid dengan desain cross sectional study dan case kontrol. Pengambilan sampel dilakukan dengan teknik purposive sampling pada ibu bersalin pada Juni sampai Agustus 2019. Sampel penelitian terdiri dari 50 plasenta ibu bersalin, yang terdiri dari 25 ibu bersalin preterm (kasus) dan 25 ibu bersalin aterm (kontrol). Hasil analisa nucleotide BLAS, didapatkan bakteri Stenotrophomonas maltophilia $(36,0 \%)$ merupakan bakteri modus tertinggi yang muncul pada plasenta preterm dan terdapat hubungan yang signifikan $(p$-value $=0.039)$ terhadap kejadian persalinan preterm dengan nilai $\mathrm{OR}=5.905$ yang berarti ibu yang terinfeksi bakteri Stenotrophomonas maltophilia mempunyai risiko 5.905 kali untuk mengalami persalinan preterm, kemudian bakteri Acinetobacter sp. $(12,0 \%)$ sedangkan modus tertinggi yang muncul pada plasenta aterm adalah bakteri Pseudomonas sp (21,7\%) dan Bacillus (13\%). Terdapat mikrobiota pada plasenta persalinan aterm maupun plasenta preterm, dan bakteri Stenotrophomonas maltophilia merupakan bakteri modus tertinggi yang muncul pada plasenta preterm dengan nilai $\mathrm{OR}=$ 5.905 yang berarti ibu yang terinfeksi bakteri Stenotrophomonas maltophilia mempunyai risiko 5.905 kali lipat untuk mengalami persalinan preterm.
\end{abstract}

Kata kunci : Plasenta, Mikrobiota, gen 16S rRNA, Preterm.

\section{ABSTRACT}

This study aims to detect bacteria in the placenta that occur most frequently and are at greatest risk for the incidence of preterm delivery using $16 S$ rRNA PCR. The research design is a hybrid with a cross sectional study and case control design. Sampling was carried out using a purposive sampling technique on mothers giving birth from June to August 2019. The research sample consisted of 50 maternal placenta, which consisted of 25 women with preterm delivery (cases) and 25 women with term delivery (control). The results of BLAS nucleotide analysis showed that Stenotrophomonas maltophilia (36.0\%) was the highest mode of bacteria that appeared in preterm placentas and there was a significant relationship ( $p$-value $=0.039)$ to the incidence of preterm delivery with OR $=5.905$, which means the mother is infected. Stenotrophomonas maltophilia bacteria have a 5,905 times risk for preterm delivery, then Acinetobacter sp. (12.0\%) while the highest mode that appeared in the placenta at term was Pseudomonas sp (21.7\%) and Bacillus (13\%). There are microbiota in both term and preterm placenta, and Stenotrophomonas maltophilia bacteria is the highest mode of bacteria that appears in preterm placenta with OR $=5.905$, which means that mothers infected with Stenotrophomonas maltophilia have a 5,905-fold risk of having preterm delivery.

Keywords: Placenta, Microbiota, 16S rRNA gene, Preterm

https://doi.org/10.33860/iik.v15i4.793

(C) 2022 by the authors. Submitted for possible open access publication under the terms and conditions of the Creative

Commons Attribution (CC BY SA) license (https://creativecommons.org/licenses/by-sa/4.0/). 


\section{PENDAHULUAN}

Persalinan preterm didefinisikan sebagai persalinan sebelum usia kehamilan 37 minggu yang merupakan penyebab utama mortalitas dan morbiditas neonatal di seluruh dunia ${ }^{(1-5)}$. World Health Organization (WHO) tahun 2013, setiap tahunnya, sekitar 15 juta bayi dilahirkan secara preterm dan lebih dari 1 juta bayi meninggal akibat komplikasi persalinan preterm. WHO (2013) juga menyebutkan bahwa Indonesia menduduki peringkat ke lima dengan persalinan preterm tertinggi di dunia ${ }^{(6,7)}$.

Kelahiran preterm di Indonesia sebagai penyumbang terbesar angka kematian dan kecacatan pada neonatal, termasuk bayi berat lahir rendah (BBLR) diikuti oleh asfiksia dan infeksi, serta sebagai penyebab kematian kedua pada balita setelah pneumonia ${ }^{(1,3,8)}$. Persalinan preterm memberikan dampak buruk terhadap pertumbuhan dan perkembangan ${ }^{(5,6)}$. Infeksi intrauteri diduga sebagai penyebab utama terhadap persalinan preterm, hal ini didukung hasil penelitian yang menunjukan adanya komunitas mikrobioma dari cairan amnion, selaput ketuban, plasenta dan mekonium bayi dari persalinan preterm ${ }^{(3,9,10)}$. Mikrobiota patogen diduga masuk kedalam plasenta melalui rute vagina, mulut, usus ${ }^{(11-13)}$ dan membentuk kolonisasi sehingga mengakibatkan infeksi ${ }^{(14)}$. Mikroorganisme tersebut merangsang toll like imun ibu melepaskan IL-1, IL-6, TNF yang merangsang produksi prostaglandin dan Matrix Metalloproteinase sehingga persalinan preterm ${ }^{(3,5,12,15)}$.

Penelitian ini bertujuan
mendeteksi bakteri plasenta
menyebabkan yang
menggunakan PCR 16S rRNA.

\section{METODE PENELITIAN}

Desain penelitian adalah hybrid dengan desain cross sectional study dan case kontrol. Pengambilan sampel dilakukan dengan teknik purposive sampling pada ibu bersalin di Rumah Sakit Khusus Daerah Ibu dan Anak Siti Fatimah Makassar, Rumah Sakit Ibu dan Anak Siti Khadija I Makassar, dan Rumah Sakit Umum Daerah Kota Makassar pada Juni sampai Agustus 2019 sesuai kriteria inklusi penelitian. Jumlah sampel sebanyak 50 yang terdiri atas 25 preterm (Kasus) dan 25 aterm (kontrol), namun yang berhasil dianalisa nucleotide BLAS adalah 48 sampel karena sebanyak 2 sampel tidak terkonfirmasi dari produk PCR. Kriteria Inklusi penelitian ini adalah ibu yang bersalin pada usia kehamilan > 22 sampai 36 minggu untuk kelompok kasus, dan $\geq 37$ minggu untuk kelompok kontrol sedangkan kriteria eklusi adalah Ibu dengan hipertensi, preeklampsia, eklampsia, gemeli, plasenta previa, solusio plasenta, HIV, dan sifilis. Variabel independen pada penelitian ini, yaitu mikrobiota plasenta, sedangkan variabel dependen, yaitu persalinan preterm. Variabel kontrol pada penelitian ini, yaitu umur, paritas, IMT, riwayat abortus, KPD dan preterm sebelumnya.

Karakteristik responden dikumpulkan menggunakan lembar check list. Pegambilan sampel plasenta dilakukan oleh analis Rumah Sakit segera setelah persalinan, sebanyak $1 \mathrm{x} 1$ $\mathrm{cm}$ menggunakan instrumen steril, sampel dipastikan bebas kontaminasi. Sampel plasenta di masukkan dalam tabung sampel kemudian ditempatkan dalam suhu $-80^{\circ} \mathrm{C}$ sampai ekstraksi DNA. Ekstraksi DNA menggunakan metode Genaid, setelah itu sampel di PCR dengan primer 16S rRNA. Hasil PCR kemudian di elektroforesis dan visualisasi gen DNA di Laboratorium Hasanuddin University Medical Research Center (HUM-RC) Makassar. Hasil visualisasi gen DNA selanjutnya dilakukan sequensing di laboratorium $1^{\text {st }}$ Base Malaysia, kemudian hasil sequensing dianalisis nucleotide BLAST Penelitian ini disetujui oleh komisi etik penelitian Universitas Hasanuddin Makassar dengan nomor : 458/UN4.6.4.5.31/PP36/2019 dan mendapat persetujuan tertulis dari semua responden.

Data dianalisis dengan SPSS versi 21.0. Data yang didapatkan dari hasil penelitian adalah non parametri sehingga analisis dilakukan uji dengan Chi-Square, KruskalWallis, Mann-Whitney dan Fisher's Exact, dan dianggap signifikan secara statistik jika p-Value $<0.05$.

\section{HASIL}

Tabel 1. Hasil analis menggunakan uji Chi-Square, Kruskal-Wallis, Mann-Whitney dan Fisher's Exact didapatkan tidak hubungan yang signifikan antara umur ( $p$-value $=0.082)$, IMT ( $p$-value 0.479$)$, Riwayat KPD ( $p$-value $0.274)$, Riwayat abortus ( $p$-value 0.641), Riwayat preterm ( $p$-value 0.077), dengan persalinan preterm, namun paritas $(0,015)$ dan 
paparan asap ( $p$-value 0.042) memiliki hubungan yang signifikan

Tabel 1. Perbandingan Karakteristik

\begin{tabular}{|c|c|c|c|c|c|}
\hline \multirow{2}{*}{ Variabel } & \multicolumn{2}{|c|}{ Preterm } & \multicolumn{2}{|c|}{ Aterm } & \multirow{2}{*}{$p$-value } \\
\hline & $\mathrm{n}$ & $\%$ & $\mathbf{n}$ & $\%$ & \\
\hline \multicolumn{6}{|l|}{ Umur } \\
\hline Risiko Tinggi & 11 & 52,4 & 10 & 47,6 & \multirow{2}{*}{$0.082^{a}$} \\
\hline Risiko Rendah & 14 & 48,3 & 15 & 51,7 & \\
\hline \multicolumn{6}{|l|}{ Paritas } \\
\hline Primipara & 15 & 68,2 & 7 & 31,8 & \multirow{3}{*}{$0.015^{\mathrm{b}}$} \\
\hline Multipara & 10 & 38,5 & 16 & 61,5 & \\
\hline Grande & 0,0 & 0,0 & 2 & 100,0 & \\
\hline \multicolumn{6}{|l|}{ Pekerjaan } \\
\hline Bekerja & 0,0 & 0,0 & 4 & 100,0 & \multirow[t]{2}{*}{$0.039^{c}$} \\
\hline Tidak Bekerja & 25 & 54,3 & 21 & 45,7 & \\
\hline \multicolumn{6}{|l|}{ IMT } \\
\hline Underweight & 4 & 66,7 & 2 & 33,3 & \multirow{3}{*}{$0.479^{\mathrm{b}}$} \\
\hline Normal & 16 & 48,5 & 17 & 51,5 & \\
\hline Overwight & 5 & 45,5 & 6 & 54,5 & \\
\hline \multicolumn{6}{|l|}{ Riwayat KPD } \\
\hline Ada & 6 & 66,7 & 3 & 33,3 & \multirow[t]{2}{*}{$0.274^{c}$} \\
\hline Tidak Ada & 19 & 46,3 & 22 & 53,7 & \\
\hline \multicolumn{6}{|l|}{ Riwayat Abortus } \\
\hline Ada & 3 & 60,0 & 2 & 40,0 & \multirow[t]{2}{*}{$0.641^{c}$} \\
\hline Tidak Ada & 22 & 48,9 & 23 & 51,1 & \\
\hline \multicolumn{6}{|l|}{ Riwayat Preterm } \\
\hline Ada & 3 & 100 & 0 & 0,0 & \multirow[t]{2}{*}{$0.077^{c}$} \\
\hline Tidak Ada & 22 & 46,8 & 25 & 53,2 & \\
\hline \multicolumn{6}{|l|}{ Paparan Rokok } \\
\hline $\mathrm{Ya}$ & 14 & 70,0 & 6 & 30,0 & \multirow{2}{*}{$0.042^{\mathrm{d}}$} \\
\hline Tidak & 11 & 36,7 & 19 & 63,3 & \\
\hline
\end{tabular}

Tabel 2. Frekuensi Modus Bakteri

\begin{tabular}{lcccc}
\hline \multirow{2}{*}{\multicolumn{1}{c}{ Bakteri }} & \multicolumn{2}{c}{ Persalinan Aterm } & \multicolumn{2}{c}{ Persalinan Preterm } \\
\cline { 2 - 5 } & $\mathrm{n}=23$ & $\%$ & $\mathrm{n}=25$ & $\%$ \\
\hline Acinetobacter $s p$. & 0 & 0,0 & 3 & 12,0 \\
\hline Chryseobacterium $s p$. & 0 & 0,0 & 1 & 4,0 \\
\hline Cupriavidus $s p$. & 1 & 4,3 & 2 & 8,0 \\
\hline Enterobacter $s p$. & 0 & 0,0 & 1 & 4,0 \\
\hline Escherichia coli & 1 & 4,3 & 2 & 8,0 \\
\hline Glutamicibacter uratoxydans & 1 & 4,3 & 1 & 4,0 \\
\hline Pseudomonas sp. & 6 & 21,7 & 2 & 8,0 \\
\hline Pseudoxanthomonas suwonensis & 1 & 4,3 & 1 & 4,0 \\
\hline Staphylococcus sp. & 0 & 0,0 & 1 & 4,0 \\
\hline Stenotrophomonas maltophilia & 2 & 13,0 & 9 & 36,0 \\
\hline Stenotrophomonas sp. & 4 & 17,4 & 2 & 8,0 \\
\hline Bacillus sp. & 3 & 13,0 & 0 & 0,0 \\
\hline Pseudoxanthomonas sp. & 2 & 8,7 & 0 & 0,0 \\
\hline Shigella flexneri & 2 & 8,7 & 0 & 0,0 \\
\hline
\end{tabular}

Tabel. 2 Hasil analisa nucleotide BLAST dari plasenta preterm frekuensi modus bakteri tertinggi adalah Stenotrophomonas maltophilia (36,0\%), kemudian Acinetobacter sp, $(12,0 \%)$ sedangkan frekuensi modus tertinggi plasenta aterm adalah Pseudomonas sp., $(21,7 \%)$ kemudian Bacillus sp. $(13,3 \%)$.

Tabel 3. Hasil uji statistik menunjukan sigifikan ( $\mathrm{p}$-value $=0.039$ ) yang artinya ada hubungan antara keberadaan bakteri Stenotrophomonas maltophilia dalam plasenta 
terhadap kejadian persalinan preterm dengan nilai $\mathrm{OR}=5.905$ yang artinya ibu yang terpapar bakteri Stenotrophomonas maltophilia mempunyai risiko 5.905 kali lipat mengalami kejadian persalinan preterm dibandingkan dengan responden yang tidak memiliki bakteri bakteri Stenotrophomonas maltophilia.

Tabel 3. Risiko Stenotrophomonas maltophilia terhadap kejadian persalinan preterm

\begin{tabular}{|c|c|c|c|c|c|c|c|c|}
\hline \multirow{3}{*}{$\begin{array}{c}\text { Bakteri } \\
\text { Stenotrophomonas } \\
\text { maltophilia }\end{array}$} & \multicolumn{6}{|c|}{ Usia Kehamilan } & \multirow{3}{*}{$p$-value } & \multirow{3}{*}{$\begin{array}{c}\text { OR } \\
\text { (CI 95\%) }\end{array}$} \\
\hline & \multicolumn{2}{|c|}{ Preterm } & \multicolumn{2}{|c|}{ Aterm } & \multicolumn{2}{|c|}{ Total } & & \\
\hline & $\mathrm{n}=25$ & $\%$ & $\mathrm{n}=23$ & $\%$ & $\mathrm{~N}$ & $\%$ & & \\
\hline $\mathrm{Ya}$ & 2 & 13,0 & 9 & 75,0 & 12 & 100,0 & \multirow{2}{*}{0.039} & \multirow{2}{*}{$\begin{array}{c}5.905 \\
(1,118-31,203)\end{array}$} \\
\hline Tidak & 21 & 56,6 & 16 & 44,4 & 36 & 100,0 & & \\
\hline
\end{tabular}

\section{PEMBAHASAN}

Berdasarkan hasil penelitian yang dilakukan pada 50 sampel plasenta yang terdiri 25 sampel plasenta persalinan aterm dan 25 sampel plasenta preterm, terdapat 2 sampel pada kontrol yang tidak terkonfirmasi dari produk PCR sehingga yang berhasil dianalisis nucleotide BLAST melalui situ NCBI pada database GenBank 48 sampel. Hasil analisis nucleotide BLAST didapatkan bakteri patogen maupun non patogen yang bervariasi dari plasenta aterm. Hasil penelitian ini menambah bukti bahwa lingkungan intrauterin tidak steril. Terdapat komunitas bakteri yang beragam dalam jaringan plasenta ${ }^{(3,16)}$. Stout MJ, et al (2013) juga menemukan bakteri intraseluler gram positif dan gram negatif yang beragam dalam piring bassal plasenta dari $54 \%$ persalinan peretrm dan $26 \%$ dari persalinan aterm ${ }^{(9)}$.

Frekuensi modus bakteri tertinggi berdasarkan hasil analisis nucleotide BLAST pada Tabel 2. dari kelompok kontrol adalah bakteri Pseudomonas sp. (21,7\%), berbeda dengan frekuensi modus tertinggi plasenta preterm adalah Stenotrophomona Maltophilia sebesar 36,0\%, bakteri ini juga menunjukan hubungan yang signifikan $(p$-value $=0.039)$ terhadap persalinan preterm dimana nilai $\mathrm{OR}=$ 5.905 yang berarti ibu yang terpapar bakteri $S$. Maltophilia mempunyai risiko 5.905 kali lipat untuk mengalami kejadian persalinan preterm dibandingkan dengan yang tidak memiliki bakteri $S$. Maltophilia. Family modus tertinggi pada plasenta preterm adalah Xanthomonadaceae, hal ini berbeda dengan penelitian sebelumnya yang menemukan lebih dominan Burkholderiaceae, Actinomycetales, dan Alphaproteobacter, ${ }^{(16)}$ hal ini disebabkan perbedaan metode dan sampel yang digunakan dalam penelitian. Sementara untuk tingkat filum, mayoritas yang terdeteksi dari plasenta preterm adalah Proteobakteria $(88,0 \%)$ dan kelompok aterm $(82,6 \%)$ sementara filum Actinobakteria, Bacteroidates, Firmicutes hanya ada dalam jumlah yang sedikit. Penelitian sebelumnya menunjukkan bahwa filum Firmicutes terdapat di vagina, filum Actinobacteria pada kulit, Proteobacteria dan Firmicutes pada di mulut, filum Bacteroidetes terdapat pada usus sedangkan Proteobacteria paling banyak pada plasenta ${ }^{(3,11)}$.

Bakteri yang terdeteksi dari plasenta aterm dan preterm menunjukan kesamaaan jenis bakteri yang terdeteksi pada serviks dari persalinan preterm dimana bakteri yang terisolasi adalah Escherichia coli (24,2\%), Staphylococci $(27,2 \%)$, Enterococcus dan candida masing-masing $(11,7 \%)$. Sampel vagina mengandung jenis bakteri tertinggi adalah Ureaplasma, Snearthia dan Lactobacillus, dan sampel dari mulut yang tertinggi adalah Nesseria, streptococcus dan Prevotella, sedangkan sampel plasenta baik dari persalinan pretem maupun aterm bakteri yang paling tinggi adalah Pseudomonas, Streptophyta, dan Enterobacteraceae (17). Bakteri yang terdeteksi pada plasenta dalam penelitian ini diduga masuk melalui vagina, mulut, usus dan membentuk kolonisasi sehingga mengakibatkan infeksi, dan menyebabkan persalinan preterm ${ }^{(3,5,12,15)}$. Hasil penelitian ini sejalan dengan penelitian sebelumnya, dengan adanya komunitas mikroba Enterobacter, Enteroccus, Lactobasilus berkorelasi dengan persalinan preterm dan bakteri ini terbukti dapat menstimulasi respon inflamasi ${ }^{(18,19)}$.

Implikasi dari penelitian ini adalah dengan menggunakan metode 16S rRNA dapat didapatkan bakteri patogen maupun non patogen yang bervariasi dari plasenta persalinan 
preterm dan maupun aterm. Hasil penelitian ini menambah bukti bahwa lingkungan intrauterin tidak sepenuhnya steril. Hasil penelitian juga menunjukan juga bahwa dalam jaringan plasenta terdapat komunitas bakteri yang beragam dan dapat memicu pelepasan sitokin inflamasi interlekuin-1, interlekuin-6 dan Tumor Necrosis Faktor yang merangsang produksi prostaglandin dan Matrix Metalloproteinase sehingga menicu terjadinya persalinan preterm.

Keterbatasan dalam penelitian ini adalah sampel tidak menggunakan teknik kultur terlebih dahulu, sehingga menyebabkan beberapa bakteri dari lempeng basal plasenta dilakukan sequensing berulang-ulang dan sulit untuk membedakan bakteri hasil analisis nucleotide pada BLAST, yang ke dua adalah masih terdapat bias dalam memcocokkan bakteri dengan genbank disebabkan rantai nukleotida dari beberapa sampel pendek dan yang ke tiga adalah responden dalam penelitian ini jumlahnya sedikit, yaitu masing-masing kelompok sebanyak 25 responden dengan jumlah keseluruhan responden sebanyak 50 responden, ini disebabkan karena keterbatasan biaya penelitian.

\section{KESIMPULAN DAN SARAN}

Berdasarkan hasil penelitian dapat disimpulkan bahwa terdapat mikrobiota pada plasenta aterm maupun plasenta preterm, dan bakteri Stenotrophomonas maltophilia merupakan bakteri modus tertinggi yang muncul pada plasenta preterm dengan nilai $\mathrm{OR}=5.905$ yang berarti ibu yang terinfeksi bakteri Stenotrophomonas maltophilia mempunyai risiko 5.905 kali untuk mengalami persalinan preterm.

\section{DAFTAR PUSTAKA}

1. Abaraya M, Seid S, Ibro S. Determinants of preterm birth at Jimma University Medical Center, southwest Ethiopia. Pediatr Heal Med Ther. 2018; Volume 9:101-7.

2. Ardissone AN, De La Cruz DM, DavisRichardson AG, Rechcigl KT, Li N, Drew JC, et al. Meconium microbiome analysis identifies bacteria correlated with premature birth. PLoS One. 2014;9(3):1-8.

3. Doyle RM, Harris K, Kamiza S, Harjunmaa U, Ashorn U, Nkhoma M, et al. Bacterial communities found in placental tissues are associated with severe chorioamnionitis and adverse birth outcomes. PLoS One. 2017;12(7).
4. Sweeney EL, Kallapur SG, Gisslen T, Lambers DS, Chougnet CA, Stephenson SA, et al. Placental Infection with Ureaplasma species is Associated with Histologic Chorioamnionitis and Adverse Outcomes in Moderately Preterm and Late-Preterm Infants. $\mathrm{J}$ Infect Dis. 2016;213(8):1340-7.

5. Cunningham, Leveno, Bloom, Hauth, Rouse, Spong. Obstetri Williams. In: Obstetri Wiliams. 2014. p. 81-4.

6. Wandita S. Nutrisi pada Bayi Prematur. Kumpul Makal Pertem Ilm Tah Ilmu Kesehat Anak VIII. 2016;180-6.

7. Global T, Report A, March of Dimes, $\mathrm{PMNCH}$ $\mathrm{S}$ the C, WHO, Eds CP Howson, MV Kinney JLWHOG. WHO 2012 Born too soon. CP Howson, MV Kinney, JE Lawn Eds World Heal Organ Publ Geneva. 2012;13(5):1-126.

8. Sulistiarini D, Berliana M. Faktor-faktor yang Mempengaruhi Kelahiran Prematur di Indonesia: Analisis Data Riskesdas 2013. Dan Lingkung. 2016;109.

9. Stout MJ, Conlon B, Landeau M, Lee I, Bower $\mathrm{C}$, Zhao Q, et al. Identification of intracellular bacteria in the basal plate of the human placenta in term and preterm gestations. Am J Obstet Gynecol. 2013;208(3):226.e1-226.e7.

10. Wang $X$, Buhimschi CS, Temoin S, Bhandari $\mathrm{V}$, Han YW, Buhimschi IA. Comparative Microbial Analysis of Paired Amniotic Fluid and Cord Blood from Pregnancies Complicated by Preterm Birth and Early-Onset Neonatal Sepsis. PLoS One. 2013;8(2).

11. Aagaard K, Ma J, Antony KM, Ganu R, Petrosino J, Versalovic J. The placenta harbors a unique microbiome. Sci Transl Med. 2014;6(237):1-22.

12. Pelzer E, Gomez-Arango LF, Barrett HL, Nitert MD. Review: Maternal health and the placental microbiome. Placenta [Internet]. Elsevier Ltd; 2017;54:30-7. Available from: http://dx.doi.org/10.1016/j.placenta.2016.12.0 03

13. Kuperman AA, Koren O. Antibiotic use during pregnancy: How bad is it? BMC Med [Internet]. BMC Medicine; 2016;14(1):1-7. Available from: http://dx.doi.org/10.1186/s12916-016-0636-0

14. Jones HE, Harris KA, Azizia M, Bank L, Carpenter B, Hartley JC, et al. Differing prevalence and diversity of bacterial species in fetal membranes from very preterm and term labor. PLoS One. 2009;4(12).

15. Cao B, Stout J, Lee I, Mysorekar U. Placental microbiome and its role in preterm birth. Neoreviews. 2014;15(12):e537-45.

16. Parnell LA, Briggs CM, Mysorekar IU. Maternal microbiomes in preterm birth: Recent progress and analytical pipelines. Vol. 41, Seminars in Perinatology. 2017. p. 392-400. 
17. Leiby JS, McCormick K, Sherrill-Mix S, Clarke EL, Kessler LR, Taylor LJ, et al. Lack of detection of a human placenta microbiome in samples from preterm and term deliveries. Microbiome. 2018;6(1):196.

18. Ardissone AN, De La Cruz DM, DavisRichardson AG, Rechcigl KT, Li N, Drew JC, et al. Meconium microbiome analysis identifies bacteria correlated with premature birth. PLoS One. 2014;9(3).

19. Koleva PT, Kim JS, Guttman DS, Sears MR, Becker AB, Mandhane PJ, et al. Impact of maternal overweight during pregnancy on the newborn gut microbiome. Birth Defects Res Part A - Clin Mol Teratol. 2015;103(5):378. 